\title{
Geographical Distribution and Impact of Backyard Chicken Varieties in India: A Retrospective Assessment
}

\author{
Vijay Kumar \\ Directorate of Poultry Research \\ Rajkumar Ullengala ( $\square$ ullengala@yahoo.com ) \\ Directorate of Poultry Research https://orcid.org/0000-0003-2712-6546 \\ L L L Prince \\ Directorate of Poultry Research \\ S V Rama Rao \\ Directorate of Poultry Research \\ R N Chatterjee \\ Directorate of Poultry Research
}

\section{Research Article}

Keywords: Backyard poultry, Chicken varieties, Retrospective assessment, Impact, Geographical distribution

Posted Date: June 30th, 2021

DOI: https://doi.org/10.21203/rs.3.rs-640952/v1

License: (c) (i) This work is licensed under a Creative Commons Attribution 4.0 International License. Read Full License 


\section{Abstract}

The data collected on distribution of improved chicken varieties over the past 25 years (1992-2017) from the ICARDirectorate of Poultry Research, Hyderabad (ICAR-DPR), poultry seed project centres (PSP) and other Government agencies who had taken parent stock from ICAR-DPR, were analysed to estimate the impact of the backyard poultry. A total of 7.56 million improved chicken germplasm (27\%) to 20.37 thousand stakeholders from ICAR-DPR, Hyderabad and 1.7 million (6.09 \%) to 28.38 thousand stakeholders from PSP were distributed during 1992-2017. Other agencies distributed 18.67 million (66.85\%) germplasm to 311.17 thousand stakeholders. The majority of the beneficiaries were from southern region (35\%) followed by central (23.4\%) and eastern (20.8\%) region of the country. Of the total varieties, Vanaraja constituted about $52 \%$ of the total germplasm followed by Gramapriya (38\%). The share of improved chicken germplasm increased from 0.01 (1992) to $0.41 \%$ (2012) in the poultry population of India i.e., from 100 to 9433 indices as compared to 100 to 244 of the country. Contribution of improved germplasm to the Indian economy increased from 1.9 (8th plan) to 62.5 (12th Plan) million USD. The total contribution during the 25 years was estimated to be about 168.7 million USD to Indian economy. Higher productivity of birds increased the income leading to socio-economic development of farmers. The study concluded that backyard poultry significantly contributed to the national economy and improved the livelihoods of the rural and tribal people, which needs to be further strengthened across the different geographical regions of the country.

\section{Introduction}

Backyard poultry (BYP) contributes about 17\% to the total egg production (103.32 billion) in India (BAHS 2019) with a significant growth rate in recent five years. The BYP has potential to alleviate poverty, eradication of malnutrition, source of subsidiary income, women empowerment, providing employment to the rural / tribal population (Chatterjee and Rajkumar 2015). Traditionally, the backyard poultry farming (BYPF) in India was mostly based on the native breeds and non-descriptive chicken varieties which has low production potential and hence became non lucrative. But introduction of improved chicken varieties resembling the native chicken with high production potential under low resource conditions strengthened and changed face of backyard poultry farming in the country. University of Agricultural Sciences, Bangalore was the first to initiate to initiate the BYPF with an improved chicken named Gritiraja during 1980s (Ramappa 2001). ICAR-Directorate of Poultry Research (ICAR-DPR), Hyderabad initiated the research work on development of chicken varieties suitable for BYPF during 1992 and developed a dual-purpose chicken variety Vanaraja and released for farmers during 1999 (Ayyagari 2001). Vanaraja has revolutionized the BYPF in India as the birds were accepted by the farmers across the country in different agroclimatic regions (Rajkumar et al. 2010). Subsequently, Gramapriya, a brown egg layer variety with an egg production potential of 160-180 eggs under free range backyard conditions was developed by ICAR-DPR, Hyderabad (Ayyagari 2001). Srinidhi, a dual purpose multicoloured bird meant for free-range and backyard farming was developed by ICAR-DPR. The Directorate also developed Janapriya for the BYPF and Krishibro for small scale broiler farming. Performance of these birds are mentioned in Table 1. These chicken varieties have become extremely popular and are being reared in majority of geographical regions of the country (Rajkumar et al. 2010; Rajkumar and Rama Rao 2015; Rajkumar et al. 2021). These chicken varieties were directly supplied to stakeholders or through governmental or non-governmental organization which accounts for about $80 \%$ of the improved backyard poultry chickens in the country (Rajkumar and Rama Rao 2018).

Poultry Seed Project (PSP) was invoked by ICAR during Eleventh Five Year plan initially at six centres and in the next plan six more six centers were added (DPR, 2014) to supply the improved backyard chicken germplasm in different parts of the country. These PSP centers act as the nodal seed centres of the improved chicken germplasm and also create awareness among the rural and tribal farmers about the advantages of BYPF. The centre multiplies parent lines supplied from DPR and distribute the chicks in their respective regions on payment basis. Parent lines are also 
supplied to state Universities, Central Poultry Development Organizations, State Animal Husbandry Departments, KVKs and other developmental agencies to propagate improved chicken among rural / tribal population. The improved chicken varieties are supplied in the form of fertile eggs, day old chicks and grownup (4-6 weeks of age) birds.

Table 1

Production potential of improved chicken varieties developed by ICAR-DPR

\begin{tabular}{|c|c|c|c|c|c|c|c|c|}
\hline \multirow[t]{2}{*}{$\begin{array}{l}\text { Sl. } \\
\text { No. }\end{array}$} & \multirow[t]{2}{*}{$\begin{array}{l}\text { Variety and Year } \\
\text { of development }\end{array}$} & \multirow[t]{2}{*}{ Purpose } & \multicolumn{3}{|c|}{ Body weight ( kg) } & \multicolumn{2}{|c|}{$\begin{array}{l}\text { Annual egg } \\
\text { production } \\
\text { (number) }\end{array}$} & \multirow[t]{2}{*}{ Reference } \\
\hline & & & $\begin{array}{l}\text { At 10-15, } \\
\text { weeks } \\
\text { (Cocks) }\end{array}$ & $\begin{array}{l}\text { At } 20 \\
\text { weeks } \\
\text { (Hens) }\end{array}$ & $\begin{array}{l}\text { At } 40 \\
\text { weeks } \\
\text { (Hens) }\end{array}$ & Farm & Backyard & \\
\hline 1 & Krishibro, 1992 & Meat & \multicolumn{2}{|c|}{$1.8-2.0$ (at 8 week) } & $\begin{array}{l}2.0 \\
(\mathrm{FCR})\end{array}$ & & & $\begin{array}{l}\text { Rajkumar } \\
\text { et al., } \\
2018\end{array}$ \\
\hline 2 & Vanaraja, 1999 & Dual & $1.5-2.0$ & $1.8-2.1$ & $\begin{array}{l}2.3- \\
2.6\end{array}$ & $\begin{array}{l}150- \\
180\end{array}$ & 110 & $\begin{array}{l}\text { Rajkumar } \\
\text { et al., } \\
2021\end{array}$ \\
\hline 3 & Gramapriya, 2001 & Egg & $1.2-1.5$ & $1.6-1.8$ & 2.3 & $\begin{array}{l}220- \\
256\end{array}$ & $160-180$ & $\begin{array}{l}\text { Rajkumar } \\
\text { et al., } \\
2021\end{array}$ \\
\hline 4 & Srinidhi, 2013 & Dual & 0.98 & & & $\begin{array}{l}195- \\
228\end{array}$ & $140-150$ & $\begin{array}{l}\text { Rajkumar } \\
\text { et al., } \\
2021\end{array}$ \\
\hline 5 & Janapriya, 2020 & Dual & $1.4-1.5$ & $1.4-1.6$ & $\begin{array}{l}1.7- \\
2.0\end{array}$ & $\begin{array}{l}185- \\
193\end{array}$ & $140-150$ & $\begin{array}{l}\text { Rajkumar } \\
\text { et al., } \\
2019\end{array}$ \\
\hline
\end{tabular}

Appreciating the successful model developed by ICAR-DPR, many academic and research institutions initiated research work for the development and propagation of improved chicken varieties in the country. Though many organizations are working on the same concept of BYPF in a scattered approach the overall impact of introducing the improved chicken varieties on national GDP and livelihood improvements is limited, rather nil in the country. Therefore, the present study brings about geospatial distribution of improved chicken varieties, impact on poultry population, their contribution in Indian economy and socio-economic impact on stakeholders of improved chicken varieties developed by ICAR-DPR, Hyderabad and propagated by different organizations spread all over the country.

\section{Materials And Methods}

As a routine practice, the details of backyard farmers who purchase improved chicken varieties are collected and stored at the Directorate for future reference of data collection on production, marketing, vaccination, disease challenge and cost benefit analysis. The primary data compiled from 1992-1993 to 2016-2017 on different parameters are utilized in the current study. Some parameters like effective population, commercial chick produced from parent stock, etc. were estimated based on standards. The data were divided into five groups as per Five-year plans of Government of India i.e., Eighth (1992-1997), Ninth (1997-2002), Tenth (2002-2007), Eleventh (2007-12) and Twelfth (2012-2017) (NITI Aayog, 2021). The primary data on germplasm distribution was collected from hatchery records and also from annual reports of the institute. As India is a very big country with vast diversity in 
climate, socio economic conditions, the country was divided into five geographical regions (IIPS 2007). These are Northern regions (Delhi, Haryana, Himachal Pradesh, Jammu and Kashmir, Panjab, Rajasthan and Uttarakhand); Central regions (Chhattisgarh, Madhya Pradesh and Uttar Pradesh); Eastern region (Bihar, Jharkhand, Odisha and West Bengal), North- Eastern region NEH - (Arunachal Pradesh, Assam, Manipur, Meghalaya, Mizoram, Nagaland, Sikkim and Tripura); Western regions (Goa, Gujrat and Maharashtra) and Southern region (Andhra Pradesh, Karnataka, Kerala, Tamil Nadu and Telangana). The data was grouped as per the regions to measure the impact of BYPF with the improved chicken varieties in different geographical regions of the country. The impact on different indicators are estimated on following method:

\section{Estimation of chicken population contribution (Effective population) N:}

$N=E \times 0.75+D o C \times 0.8+(P \times 0.8 \times 52.75)+G+P S P$

Where,

$E=$ No. of fertile egg supplied,

0.75 = Average Hatchability $(75 \%)$ calculated on available data,

DoC = Day Old Chick supplied,

0.8 = Survivability of DoC (20\% mortality: Rajkumar et al. 2018; Islam et al. 2020)

$\mathrm{P}=$ Parent Population supplied to different organization (other than PSP) and multiplied by 0.8 to get female parent population (Average parent supply in 80:20 ratio of female and male),

52.75 = Average number of chicks supplied to stakeholders from each female parent (Average of PSP Centers),

$\mathrm{G}=$ Grownup birds supplied to stakeholders,

PSP = Germplasm distributed through Poultry Seed Project

\section{Calculation of Index (I)}

$\mathrm{I}=\left(\sum \mathrm{P}_{1} / \sum \mathrm{P}_{0}\right) \times 100($ Gupta 2011)

Where,

$\mathrm{P}_{0}=$ Population at base year

$\mathrm{P}_{1}=$ Population at year in consideration

The population of fowl in the year 1992 was considered as base year.

\section{Estimation of Contribution to National Economy (E):}

$E=[N / 2 \times 210]+[N / 2 \times 765]$

Where,

$\mathrm{N}=$ Effective number of germplasms contributed to Indian chicken population, 
₹ 210 and 765 = Average gain from male and female birds, respectively (Rajkumar et al. 2018)

\section{Estimation of Adopters}

The average number of birds per beneficiary was about 60 birds based on the total number of birds distributed and total number of beneficiaries as per the available data of PSP and other organisations.

Number of Adopters get benefited $(\mathrm{N})$ :

$N=x+y+z$

Where,

$x=$ Number of beneficiaries from DPR (Actual number)

$y=$ Number of beneficiaries from PSP centres (Estimated number)

$z=$ Number of beneficiaries from Other organisations (Estimated number)

(So, $y$ and $z=$ Number of total germplasm distributed/60)

\section{Results And Discussion}

India is a vast country having 28 states and 8 Union Territories (UT) with 3.3 million sq. km area (Government of India 2021). ICAR-DPR germplasms has been adopted by farmers of all the states and UT except one, i.e., Dadra and Nagar Haveli and Daman and Diu. It shows vast geographical distribution and wider acceptance of improved chicken germplasm among the stakeholders due to the merit of better adaptability and higher productivity these improved birds in the diversified geographic regions all through the country. The gradual increase in the number of states in different plan period for adopting the BYP is presented in Table 2. During the 25 years, a total of 7.56 million germplasm was directly distributed by ICAR-DPR to the farmers and other stakeholders which was about $27 \%$ of all improved chicken germplasm (27.93 million). PSP centers, started in the Twelfth five-year plan and distributed $6.09 \%$ of total germplasm. Majority of the improved germplasm (66.85\%) was supplied from Universities, Central Poultry Development Organizations, State Animal Husbandry Departments, other developmental agencies and few private entrepreneurs. These organisations taken parent lines from ICAR-DPR and produced day old chicks to supply among the stakeholders. The process of supply improved germplasm was initiated during Eighth five-year plan and in the subsequent plan (Ninth) period highest growth (950\%) was recorded. After inception of PSP centres in Tenth plan, further growth of $185 \%$ was noticed in the germplasm supply. The introduction of improved germplasms in backyard sector and revolution in poultry industry reflected in increased share of poultry meat to total meat production of the country. The contribution of poultry in domestic meat production has increased from $23 \%$ in $2004-05$ to $51 \%$ in 2009 10 in the country. Poultry is the cheapest source of animal protein and has wider acceptability across the regions and religions compared to other meats (Manning and Baines 2004). The increased availability poultry produce and affordability of consumers of both rural and urban areas had contributed to the increased consumption of egg and chicken meat leading to improved nutritional status of rural and tribal population (Pica-Ciamarra and Otte 2010). 
Table 2

Distribution of improved germplasms in India during five-years plan periods (million)

\begin{tabular}{|c|c|c|c|c|c|c|}
\hline \multirow[t]{2}{*}{ Plan Period } & \multirow[t]{2}{*}{ Years } & \multirow[t]{2}{*}{ States / UT } & \multicolumn{3}{|c|}{ Germplasm supplied by } & \multirow[t]{2}{*}{ Total } \\
\hline & & & ICAR-DPR & PSP centres & Other organizations & \\
\hline Eighth & 1992-1997 & 14 & 0.32 & - & - & 0.32 \\
\hline Ninth & 1997-2002 & 22 & 1.56 & - & 1.80 & $3.36(950)$ \\
\hline Tenth & $2002-2007$ & 27 & 1.59 & - & 2.01 & $3.6(7.14)$ \\
\hline Eleventh & $2007-2012$ & 29 & 2.27 & 0.24 & 7.76 & $10.27(185)$ \\
\hline Twelfth & $2012-2017$ & 29 & 1.83 & 1.46 & 7.10 & 10.39 (1.17) \\
\hline Total & $1992-2017$ & $35 \#$ & 7.56 & 1.7 & 18.67 & 27.93 \\
\hline Percent share & of germplasm & & 27.07 & 6.09 & 66.85 & 100 \\
\hline \multicolumn{7}{|c|}{ *Estimation based on parents supply to different organization from ICAR-DPR } \\
\hline \multicolumn{7}{|c|}{ Figures in parentheses indicate percent change compare to last figure in column } \\
\hline
\end{tabular}

Major proportion (78.3\%) of the improved chicken germplasm was supplied to southern part of the country followed by Eastern (10\%), which might be due to the location advantage of the institute and the awareness of the farmers in poultry farming activities in the region. Southern region accounts for more than $60 \%$ of poultry production in the country. Eastern region, especially NEH region adopted the backyard poultry in a big way as the region has inherent difficulties for establishment of commercial poultry. At the same time, the lush green backyards, suitable environment, food habits of the people were the other factors responsible for the success of the backyard poultry in NEH region. Minimum proportion of the germplasm was supplied to Northern (0.6\%) and Central region (1.85\%) region of India. The reason might be lack of awareness and food habits as sizable proportion of the population is vegetarian. PSP centres established to make available the quality poultry seed benefitted Eastern (44\%) and NEH (42.8\%) regions (Table 3), whereas, Western region got minimum germplasm ( $0.2 \%)$. The probable reason might be the food habits of the people and low demand for the poultry products in the region. Among the total supply, about $6.23 \%$ was parent lines which were supplied to many Government organisations, which in turn rear the parents, produce day old chicks and distribute to the farmers and other stakeholders in their region. The availability of the quality improved poultry seed across the country in Govt organizations made easy access to the seed (fertile eggs and day old chicks) and reduced the transportation costs and logistic issues to the farmers. Major change was observed in Central region and Western region, where in Government organizations played a major role in propagation of improved chicken germplasm. 
Table 3

Distribution of improved germplasms (million) in different regions of India during 1992-2017

\begin{tabular}{|lllll|}
\hline \multirow{2}{*}{ Geographic regions of India } & \multicolumn{2}{l}{ Germplasm supplied by } & \multirow{2}{*}{ Total } \\
\cline { 2 - 4 } & DPR & PSP centers & Other organizations* \\
\hline Central & $0.14(1.85)$ & $0.08(4.69)$ & $4.96(26.57)$ & 5.18 \\
\hline Eastern & $0.76(10.05)$ & $0.75(44.01)$ & $3.71(19.87)$ & 5.22 \\
\hline Northern & $0.05(0.66)$ & $0.01(0.59)$ & $0.36(1.93)$ & 0.42 \\
\hline North-Eastern & $0.38(5.03)$ & $0.73(42.84)$ & $1.79(9.59)$ & 2.9 \\
\hline Southern & $5.92(78.31)$ & $0.14(8.22)$ & $6.33(33.9)$ & 12.39 \\
\hline Western & $0.30(3.97)$ & $0.004(0.23)$ & $1.52(8.14)$ & 1.82 \\
\hline Total & 7.56 & 1.704 & 18.67 & 27.93 \\
\hline *Estimation based on parents supply to different organization from DPR & \\
\hline Figures in parentheses indicate percent share between the regions (in the column) & \\
\hline
\end{tabular}

Out of all improved backyard chicken varieties developed by ICAR-DPR, Vanaraja was predominating variety, which transformed the backyard poultry in the country. Vanaraja was well adopted and accepted by the farmers in all the geographical regions of the country except central and southern regions, the probable reasons may be its appearance similar to the native birds, multi-coloured plumage, higher egg production and growth rate, ability to thrive in diversified climates, meat quality, egg colour, etc. however, the share of Gramapriya in Central and Southern region was more. Vanaraja constituted about $52 \%$ followed by Gramapriya about $38 \%$ in the country. In Northern and Eastern region Vanaraja constituted about $88 \%$ and $85 \%$, respectively. Whereas, its contribution was about $70 \%$ in Western, about 50 \% in North-Eastern and Central region (Fig. 1). Vanaraja and Gramapriya accounts for almost $80 \%$ of the improved backyard chicken germplasm in India; which demonstrate the success of the technologies developed by ICAR and reached to the end users who are at the bottom of the pyramid, the poor landless rural and tribal people.

The geographical distribution of different chicken varieties is presented in Fig. 2. Krishibro chicken mostly preferred in southern region (56\%) as it was an established coloured meat purpose chicken. As the southern region dominates the non vegetarian population, the Krishibro adoption and consumption was higher. Vanaraja was predominant in southern (34.5\%) and Eastern regions (30\%) of India. Srinidhi was mostly supplied in North-Eastern region followed by Southern region (22.8\%). Gramapriya was mostly liked in Southern region (56\%) followed by Central (25\%) and NorthEastern (10.9\%) regions of India. Krishilayer was mostly dominated in Southern region (83.3\%) of the country.

Vanaraja, a dual-purpose chicken variety, was hardy and had better immune competence, thus well adopted for rearing under harsh and diversified climatic conditions. This variety was well accepted in all agro climatic zones of the country. It was the first improved chicken variety which got acceptability across all geographical regions of the country (Rajkumar et al, 2018). Vanaraja and Gramapriya were the major varieties supplied through PSP centers in their respective regions. The higher B:C (full form) ratio and higher net return per bird in case of Vanaraja indicates that Vanaraja rearing is much more profitable than the local chicken (Singh et al. 2019). Ramana et al. (2010) recorded that the total income was more than three folds higher for Vanaraja (₹ 371.20) than desi bird (₹ 99.90) indicating that rearing Vanaraja chicken was more profitable under backyard system. The Vanaraja birds had high demand in rural backyard production due to better performance which was a viable alternative to ensure nutritional security, sustainable livelihood and employment generation to local population (Sankhyan and Thakur 2016). 
The five attributes that encourage an individual to adopt a new technology were: relative advantage, compatibility, complexity, trialability and observability (Rogers 2003). Any good technology having majority of these characteristics will be adopted by large section of stakeholders. The improved chicken varieties developed by ICAR-DPR, Hyderabad possess the above attributes of adoption process resulting in the large scale adoption of these birds across the country. Two types of stakeholders adopted the DPR germplasm; stakeholders with individual capacity and stakeholders in the capacity of firms/ organizations/ academic institutions etc.

Table 4

Distributions of DPR improved poultry beneficiaries in different five-year plan periods (thousand)

\begin{tabular}{|llllll|}
\hline \multirow{2}{*}{ Five-year plan } & Years & \multicolumn{2}{l}{ Beneficiaries } & Total \\
\cline { 3 - 5 } & & DPR & PSP Centers* & Others Organizations * \\
\hline Eighth & $1992-1997$ & 0.53 & - & - & 0.53 \\
\hline Ninth & $1997-2002$ & $4.2(692)$ & - & 30.00 & $34.2(6352.8)$ \\
\hline Tenth & $2002-2007$ & $3.68(-12)$ & - & $33.50(11.67)$ & $37.18(8.7)$ \\
\hline Eleventh & $2007-2012$ & $5.13(39)$ & 4.03 & $129.33(286.06)$ & $138.49(272.5)$ \\
\hline Twelfth & $2012-2017$ & $6.83(33)$ & $24.35(504)$ & $118.33(-8.51)$ & $149.51(8.0)$ \\
\hline Total & $1992-2017$ & 20.37 & 28.38 & 311.17 & 359.92 \\
\hline Percent share & & 5.66 & 7.89 & 86.46 & 100.00 \\
\hline *Estimated; & & & & \\
\hline Figures in parentheses indicate percent change compare to last figure in column & \\
\hline
\end{tabular}

The improved chicken varieties were supplied directly either in the form of day old chicks or grown up (4-6 weeks of age) chicks from ICAR-DPR, from 12 PSP centres to different parts of the country. Similar supply was made by other Government organisations like State Animal Husbandry Department (ADH), Central Poultry Development Organisations (CPDO), Central Government Agencies, state Universities, Krishi Vigyan Kendra (KVK), etc. Majority of the beneficiaries (86.5\%) got birds from other Government organisations (Table 4). DPR accounts for only $5.66 \%$ and PSP centres for $7.89 \%$ of stakeholder during the study period. The trends in other plan periods were similar. In the Ninth plan period, major increment (692\%) was recorded in DPR beneficiaries. Overall, $6352 \%$ increase was noticed in Ninth plan followed by Eleventh plan (272\%) period. The quantum jump in Ninth plan period might be due to the initiation of project during Eighth plan and subsequently the awareness about the technology and its acceptability increased many folds during the subsequent Ninth plan period. 
Table 5

Distributions of DPR improved poultry beneficiaries in different geographical regions of India (thousand)

\begin{tabular}{|lllll|}
\hline Regions & \multicolumn{2}{l}{ Beneficiaries } & \multicolumn{2}{l}{ Total } \\
\cline { 2 - 4 } & DPR & PSP Center* & Other Organizations * & \\
\hline Central & $0.12(0.59)$ & $1.33(4.69)$ & $82.67(26.57)$ & $84.12(23.37)$ \\
\hline Eastern & $0.52(2.55)$ & $12.48(43.97)$ & $61.83(19.87)$ & $74.83(20.79)$ \\
\hline Northern & $0.07(0.34)$ & $0.17(0.6)$ & $6.00(1.93)$ & $6.24(1.73)$ \\
\hline North-Eastern & $0.29(1.42)$ & $12.17(42.88)$ & $29.83(9.59)$ & $42.29(11.73)$ \\
\hline Southern & $18.99(93.23)$ & $2.33(8.21)$ & $105.50(33.9)$ & $126.82(35.24)$ \\
\hline Western & $0.38(1.87)$ & $0.07(0.25)$ & $25.33(8.14)$ & $25.78(7.16)$ \\
\hline Total & 20.37 & 28.38 & 311.17 & 359.92 \\
\hline
\end{tabular}

Figures in parentheses indicate percent share between the regions (in the column)

Most of the beneficiaries were from Southern region (93\%), it might be due to accessibility of nearby stakeholders (Table 5). To meet the demand of other regions PSP centres were initiated at 12 places in different regions. Under the PSP centres, majority of the beneficiaries were from Eastern (about 44\%) and North-Eastern (about 43\%) regions. From other organizations, majority of the beneficiaries were from Southern region (about 34\%) followed by Central (26.5\%) and Eastern (19.9\%). Overall, majority of the beneficiaries were from Southern region (about 35\%) followed by Central (23.4\%) and Eastern (20.8\%). There was least participation of beneficiaries from the Northern region (1.7\%). The pattern of adoption of the backyard poultry with the improved birds revealed that the location of the institute/organization, easy access to the birds and technical inputs and food habits of the people played a major role in adoption of the technology.

Improved chicken varieties developed by DPR were adopted in almost all parts of the country. Productivity of these improved birds was 2 to 3 times higher than the native birds (Singh et al. 2018). Production performance of improved birds varied in different regions of the country as reported by different researcher (Rajkumar et al., 2021).

\section{Impact of the technology}

The impact of the backyard poultry technology was assessed based on the three indicators i.e. Share of germplasms in Indian chicken population, contribution to Indian economy and socio-economic development of stakeholder (improved egg and meat availability and income generation).

\section{Share of germplasms in Indian fowl population}

Estimated population of germplasm available in different parts of the country is presented in Table 6 . The results revealed continuous increment in the share of the total chicken) population from 0.01 (1992) to 0.41\% (2012). During the period, chicken population in India had increased by 52.6, 41.3, 0.8, 12.1 and 16.6 percent during 1992-1997, 1997-2003, 2003-2007, 2007-2012 and 2012-2019, respectively (19th Livestock Census Report 2012; 20th Livestock Census Report 2019). The corresponding increase in improved chicken germplasm contribution was much higher (Table 6). The improved germplasm has grown from 100 to 9433 Indices; whereas as per census country fowl indices moved from 100 to 244 points. It clearly revealed that the improved chicken germplasm, which resemble the 
native chicken and perform better that the native chicken number increased at much faster rate compared to the other fowls. This may be due to the higher adoption and acceptance of the improved chicken by farmer and higher productivity and ease of adaptation to diversified agro-climatic conditions. The contribution of improved chicken germplasm always showed a positive growth trend, indicating constant increase in acceptability of the these chicken varieties in newer areas and by large population.

Table 6

Share of DPR germplasms in Indian fowl population (millions)

\begin{tabular}{|lllllll|}
\hline \multirow{2}{*}{ Livestock census } & Years & \multicolumn{2}{l}{ Indian fowl population } & \multicolumn{2}{l}{ DPR Contribution } & \multicolumn{2}{l}{ Percentage share } \\
\cline { 3 - 6 } & & Population & Index & Population & Index & \\
\hline 15th & 1992 & 284.0 & 100 & 0.03 & 100 & 0.01 \\
\hline 16th & 1997 & $433.4(52.6 \%)$ & 153 & $0.21(600 \%)$ & 700 & 0.05 \\
\hline 17th & 2003 & $612.5(41.3 \%)$ & 216 & $0.53(152.4 \%)$ & 1767 & 0.09 \\
\hline 18th & 2007 & $617.7(0.8 \%)$ & 217 & $2.48(367.9 \%)$ & 8267 & 0.40 \\
\hline 19th & 2012 & $692.7(12.1 \%)$ & 244 & $2.83(14.1 \%)$ & 9433 & 0.41 \\
\hline Figures in parentheses indicate percent change compared to previous data in the column
\end{tabular}

\section{Contribution to Indian economy}

Productivity of the improved germplasm was higher than that of native breeds and local non-descript birds. These birds are used for egg as well as meat production. The contribution of improved germplasm to Indian economy is presented in Table 7. During the Eight plan, contribution of was 1.9 million USD and subsequently increased to 62.5 million USD in Twelfth plan. The total estimated contribution of improved chicken germplasm to Indian economy was about 168.7 million USD during the 25 years of study period. 
Table 7

Contribution of improved chicken germplasm in Indian poultry population (in million) and Indian Economy (million USD)

\begin{tabular}{|lllllllll|}
\hline $\begin{array}{l}\text { Five- } \\
\text { year } \\
\text { plan }\end{array}$ & $\begin{array}{l}\text { Fertile } \\
\text { eggs }\end{array}$ & $\begin{array}{l}\text { Day } \\
\text { old } \\
\text { chicks }\end{array}$ & $\begin{array}{l}\text { PSP } \\
\text { germplasm }\end{array}$ & $\begin{array}{l}\text { Other* } \\
\text { organizations }\end{array}$ & $\begin{array}{l}\text { Grownup } \\
\text { birds }\end{array}$ & Total & $\begin{array}{l}\text { Effective } \\
\text { population } \\
\text { contribution\# }\end{array}$ & $\begin{array}{l}\text { Contribution } \\
\text { to Indian } \\
\text { economy at } \\
\text { current price } \\
\text { (million } \\
\text { USD) }\end{array}$ \\
\hline Eighth & 0.18 & 0.13 & - & - & & & & \\
\hline Ninth & 1.20 & 0.35 & - & 1.80 & 0.00 & 0.31 & 0.24 & 1.9 \\
\hline Tenth & 1.16 & 0.37 & - & 2.01 & 0.01 & 3.55 & 3.19 & 21.8 \\
\hline Eleventh & 1.27 & 0.76 & 0.24 & 7.76 & 0.03 & 10.06 & 9.59 & 61.8 \\
\hline Twelfth & 0.49 & 1.10 & 1.46 & 7.10 & 0.02 & 10.17 & 9.83 & 62.5 \\
\hline Total & 4.31 & 2.72 & 1.7 & 18.67 & 0.06 & 27.46 & 25.84 & 168.7 \\
\hline \#Deduction of mortality and hatchability & & & & & \\
\hline *Estimation based on parents supply to different organization from DPR & & & \\
\hline
\end{tabular}

\section{Socio-economic development of stakeholders}

The Indian poultry sector, today (2019-20) contributes about 17 billion USD to India's Gross Domestic Product (GDP), besides providing livelihoods and employment to millions. Backyard poultry has an important role in socio economic development of the rural tribes for centuries. The native chicken varieties adopted in free- range backyard conditions for centuries contribute about $11 \%$ of total egg production in India (Kumaresan et al. 2008). Due to their low productivity (annual egg production: 50-60 nos.), their contribution to the total egg output was almost static for the last few decades (Islam et al. 2020) and presently its contribution reached to about $17 \%$ to the total egg production (103.32 billion) of the country (BAHS 2019). Market studies showed that prices per kg live weight for these birds found to be $50-100 \%$ higher than that of commercial broilers (Conroy et al. 2005). The impact of these poultry birds is not only limited to income earning but also have effective role in food and nutritional security, employment generation and gender equity in most of the underdeveloped and developing countries (Sharma 2020). Backyard poultry plays an important role in poverty alleviation by means of income generation and household food security (FAO 1997). Higher productivity of the improved birds led to higher income which was utilised by stakeholders for their socio-economic development. The impact was clearly noticed in NEH region with farmers earning sizable amount by rearing Vanaraja birds where benefit-cost (B: C) ratio was recorded as 4.41 as compared to local chicken of 1.57 (Singh et al. 2019).

Introduction of improved chicken varieties resembling the native chicken and able to adapt in diversified geographic regions with higher productivity strengthened and revolutionised the backyard poultry farming in the country. The returns from the backyard poultry rearing increased minimum 2 to 3 times to the farmers. Now a days, farmers have wide range of options for improved backyard chicken developed by many research organizations that are either available at their door step or nearby their area. Backyard poultry with improved chicken germplasm led to the nutritional security, employment generation and livelihood improvements in the rural and tribal areas of the country. The backyard poultry should be given more focus to expand further to rural masses for targeting the production by masses rather than mass production which will improve the share of backyard poultry to economy as well as chicken population. 


\section{Declarations}

\section{Acknowledgement}

Authors are thankful to all staffs of hatchery unit of ICAR-DPR, Principal investigators of PSP Centers, In charges of farm and hatchery for their cooperation in sharing the data.

Funding The research project was funded by Indian Council of Agricultural Research- Directorate of Poultry Research, Hyderabad, India.

Conflict of interest The authors declare no competing interests.

Animal Ethics Ethics approval is not required. The manuscript does not involve the live animal. The manuscript was based on the data collected from the different identified sources from different geographic regions.

Data availability The data can be made available on request, if needed.

Code availability Not applicable

Author contributions All authors contributed in conceptualization of the article. The first author analysed the data and prepared the manuscript. Dr. Rajkumar critically reviewed the article and supplemented the information. Dr Prince provided the data and edited the manuscript. Dr. Rama Rao critically reviewed and edited and improved the article. Dr. Chatterjee edited the article. All have contributed in improving the article.

\section{References}

1. 19th Livestock Census Report., 2012. 19th Livestock Census Report -2012 All India Report. Ministry of Agriculture Department of Animal Husbandry, Dairying and Fisheries Krishi Bhawan, New Delhi.

2. 20th Livestock Census Report., 2019. 20th Livestock Census Report -2019 All India Report. Ministry of Fisheries, Animal Husbandry \& Dairying, Krishi Bhawan, New Delhi.

3. Ayyagari, V., 2001. Development of varieties for rural poultry. In: Souvenir on Sustainable Poultry production: Rural and commercial approach. $3^{\text {rd }}$ March, Hyderabad, India, pp. 7-14.

4. BAHS (Basic Animal Husbandry Statistics)., 2019. Department of Animal Husbandry, Dairying and Fisheries, Government of India. Accessed Feb. 2020.

https://dahd.nic.in/sites/default/filess/BAHS\%20\%28Basic\%20Animal\%20Husbandry\%20Statistics2019\%29_0.pdf.

5. Chatterjee, R.N., and Rajkumar. U., 2015. An overview of poultry production in India. Indian Journal of Animal Health, 54(2), 89-108.

6. Conroy, C., Sparks, N., Chandrasekaran, D., Sharma, A., Shindey, D., Singh, L.R., Natarajan, A. and Anitha, K., 2005. Improving backyard poultry-keeping: a case study from India. Agricultural Research and Extension Network (AgREN). pp. 146.

7. DPR., 2014. Annual Report- 2013-14. ICAR-Directorate of Poultry Research Rajendranagar, Hyderabad-500 030, Telangana, India.

8. FAO., 1997. (Food and Agriculture Organization of the United State Nations). Guidelines for the inclusion of improved household poultry production. Diversification component of the special programme for food security Rome. 
9. Government of India., 2021. https://www.india.gov.in/india-glance/profile

10. Gupta, S.P., 2011. Statistical Methods. Sultan Chand \& Sons, New Delhi. pp-523.

11. IIPS., 2007. International Institute for Population Sciences (IIPS) and Macro International. National Family Health Survey (NFHS-3), 2005-06: India: Volume I. Mumbai: IIPS. pp-15.

12. Islam, R., Sapcota, D., Saikia, A.K. and Sheikh, I.U., 2020. Performances of Improved Dual Type Backyard Chicken in Free Range System: A Review. Journal of Poultry Science and Technology, 8(2), 32-40.

13. Kumaresan, A., Bujarbaruah, K.M., Pathak, K.A., Chhetri, B., Ahmed, S.K. and Haunshi, S., 2008. Analysis of a village chicken production system and performance of improved dual purpose chickens under a subtropical hill agro-ecosystem in India. Tropical Animal Health and Production, 40, 395-402.

14. Manning, L. and Baines. R.N., 2004. Globalisation: a study of the poultry-meat supply chain. British Food Journal, 106 (10/11), 819-836.

15. NITI Aayog., 2021. https://niti.gov.in/planningcommission.gov.in/docs/plans/planrel/fiveyr/index5.html (Accessed on 20.4.2021).

16. Pica-Ciamarra, U. and Otte, J., 2010. Poultry, food security and poverty in India - looking beyond the farm-gate. World's Poultry Science Journal, 66, 309-319.

17. Rajkmuar, U., Rama Rao, S.V., Raju, M.V.L.N. and Chatterjee, R.N., 2021. Backyard poultry farming for sustained production and enhanced nutritional and livelihood security with special reference to India: a review. Tropical Animal Health and Production, 53,176 https://doi.org/10.1007/s11250-021-02621-6

18. Rajkumar, U., and Rama Rao. S.V., 2015. Gramapriya, a prolific brown egg layer for rural backyards. Indian Farming, 65, 32-34.

19. Rajkumar, U., and Rama Rao. S.V., 2018. Rural poultry: A potential tool for poverty alleviation and nutritional security. In: Souvenir of 35th annual conference and National symposium of Indian Poultry Science Association on Rural poultry production: challenges for sustainable entrepreneurship development. pp 161-170.

20. Rajkumar, U., Haunshi, S., Paswan, C., Reddy, B.I.N., and Yadav, S.P., 2018. Evaluation of three-way crossbred chicken developed for rural poultry under farm and backyard conditions for growth and production traits. Indian Journal of Animal Sciences, 88 (2), 229-232.

21. Rajkumar, U., Haunshi, S., Paswan, C., Prakash, B., Padhi, M.K., and Rama Rao, S.V., 2019. Evaluation of two-way cross developed for free range poultry farming under farm and free range conditions. Indian Journal of Animal Sciences, 89 (6), 652-657.

22. Rajkumar, U., Rama Rao, S.V., and Sharma. R.P., 2010. Backyard poultry farming: Changing the face of rural India. Indian Farming, 59, 20-23.

23. Rajkumar, U., Rama Rao, S.V. and Chatterjee, R.N., 2018. Improved chicken varieties. ICAR-DPR Publication, pp 142.

24. Ramana, D.V.B., Nirmala, G., Maruthi, V. and Rap, G.R., 2010. Performance of Vanaraja birds as backyard poultry. Indian Veterinary Journal, 87, 517-518.

25. Ramappa, B.S., 2001. Development of varieties for rural poultry. In : Souvenir on Sustainable Poultry production: Rural and commercial approach. 3rd March, Hyderabad, India, pp. 1-6.

26. Rogers, E.M. 2003. Diffusion of innovations. Free Press. New York, 551.

27. Sankhyan, V. and Thakur, Y.P., 2016. Comparative Performance of Vanaraja and Indigenous Chicken Under Intensive System in Sub Temperate Climatic Condition of North Western Himalayan State of Himachal Pradesh. International Journal of Science, Environment and Technology, 5(2), 449 - 453.

Page $13 / 14$ 
28. Sharma, E.K. 2020. Coronavirus: Chicken, eggs sale crash; Indian poultry loses ₹ 1,100 crore. Business Lines (March 9, 2020)

29. Singh, M., Islam, R. and Avasthe, R., 2019. Socioeconomic Impact of Vanaraja Backyard Poultry Farming in Sikkim Himalayas. International Journal of Livestock Research, 9(3), 243-248. doi:10.5455/ijlr.20181029045005.

\section{Figures}

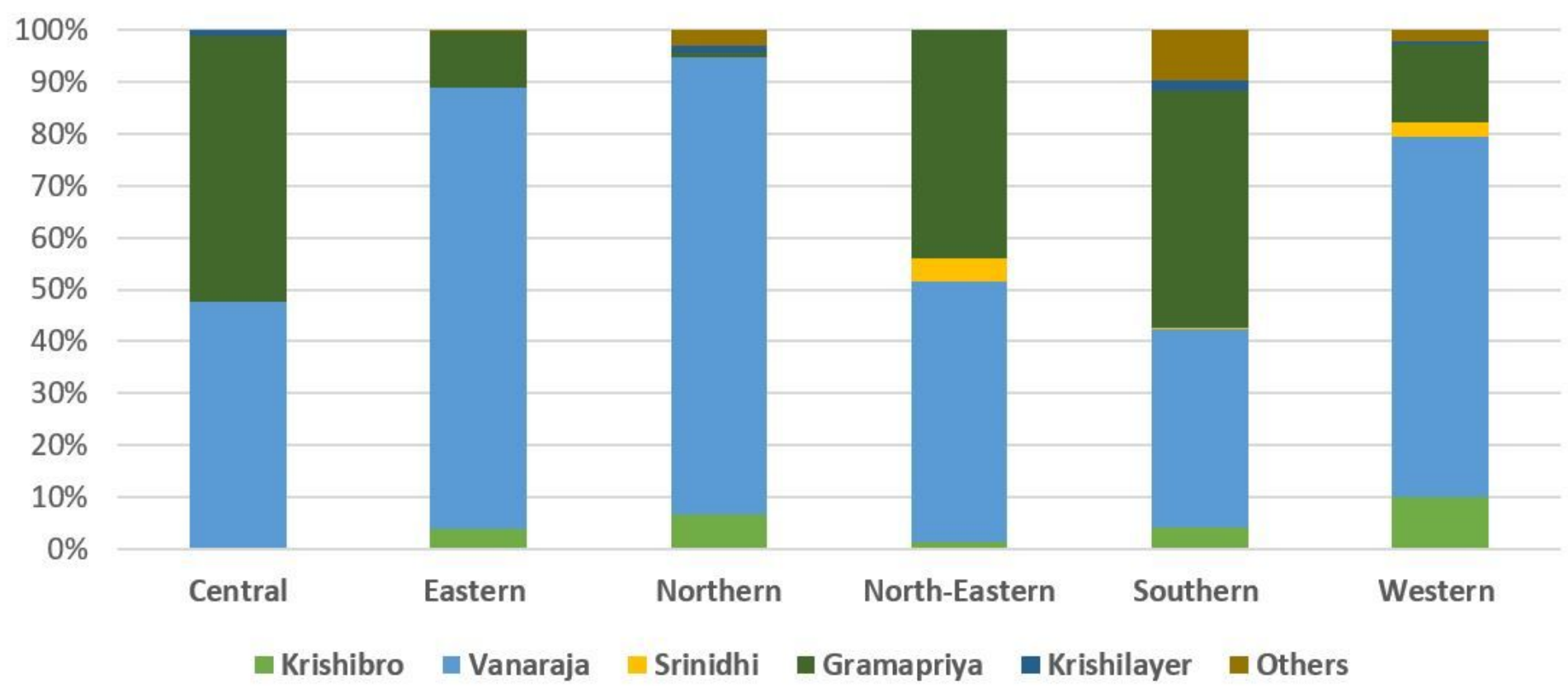

Figure 1

Percentage share of different improved varieties of ICAR-DPR within geographical regions of India

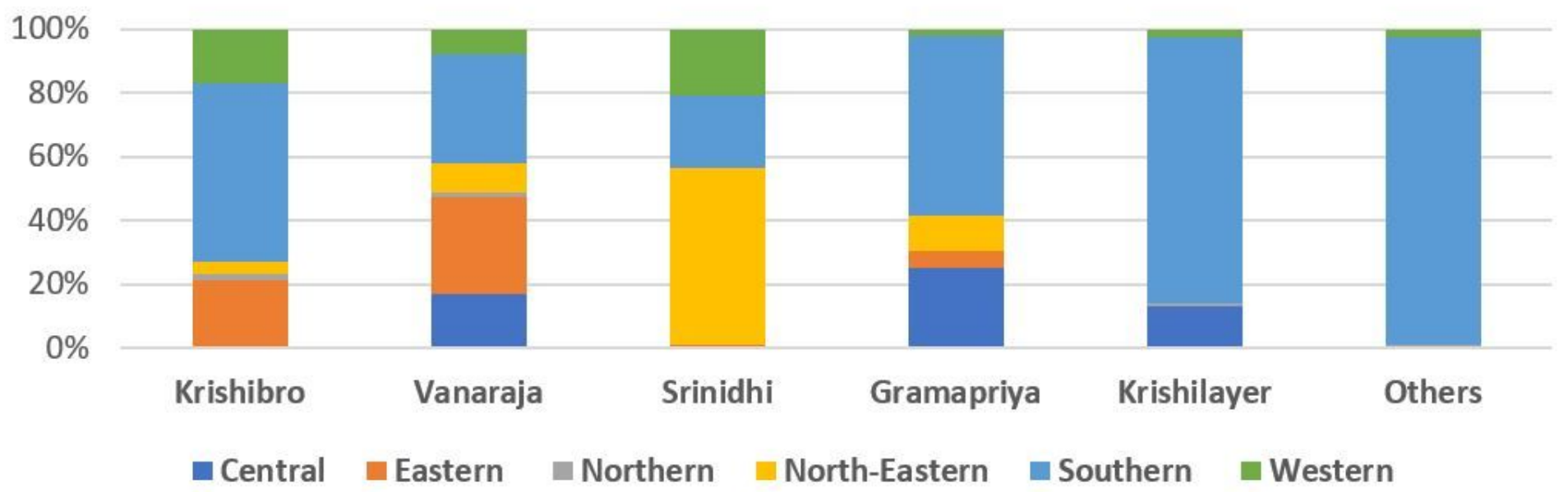

\section{Figure 2}

Percentage share of different improved varieties of ICAR-DPR between the geographical regions of India 